\title{
Mulemba
}

Revista Angolana de Ciências Sociais

5 (10) | 2015

Angola 40 anos de independência: memória, identidades, cidadania e desenvolvimento

\section{Paradoxos e pragmatismos nos primeiros anos da Nação Angolana}

\section{Rodrigues Vaz}

\section{(2) OpenEdition \\ Journals}

Edição electrónica

URL: http://journals.openedition.org/mulemba/2182

DOI: $10.4000 /$ mulemba.2182

ISSN: 2520-0305

\section{Editora}

Edições Pedago

\section{Edição impressa}

Data de publição: 1 novembro 2015

Paginação: 823-827

ISSN: 2182-6471

Refêrencia eletrónica

Rodrigues Vaz, «Paradoxos e pragmatismos nos primeiros anos da Nação Angolana», Mulemba [Online], 5 (10) | 2015, posto online no dia 13 outubro 2018, consultado o 27 janeiro 2021. URL: http:// journals.openedition.org/mulemba/2182 ; DOI: https://doi.org/10.4000/mulemba.2182 


\title{
Paradoxos e pragmatismos nos primeiros anos da Nação Angolana*
}

\author{
Rodrigues Vaz ${ }^{* *}$
}

Primeiro livro publicado em Angola de um brasileiro que foi um dos maiores militantes do Movimento Negro no Brasil, José Maria Nunes Pereira, recentemente falecido, O paradoxo angolano: Uma política externa em contexto de crise (1975-1994) traz-nos uma análise tão objectiva como descomprometida, tão ousada como original dos primeiros anos da independência em Angola.

Denominando como paradoxo angolano o facto de Angola protagonizar com o maior pragmatismo possível o engajamento político com o bloco de Leste e a sua doutrina marxista-leninista, por um lado, e a sua quase total independência dos investimentos, comércio e negócios com o Ocidente, por outro lado, reconhece que a solução desse paradoxo foi finalmente favorável ao modelo Ocidental, através da integração crescente e institucional de Angola à economia de mercado, aos organismos internacionais que regem essa economia.

Na verdade, do ponto de vista político-militar, houve afastamento das alianças com o bloco socialista, bem como a adopção da democracia pluripartidária, tendo o Movimento Popular de Libertação de

* Recensão a obra de José Maria Nunes Pereira, O Paradoxo Angolano. Uma política externa em contexto de crise (1975-1994). Prefácio de Manuel Inácio dos Santos Torres. Luanda, Editorial Kilombelombe, 2015, 452p. [Ciências Humanas e Sociais - Série Ciência Política e Relações Internacionais»; 1]. Este texto foi inicialmente publicado na revista África 21 (Luanda), n. ${ }^{\circ}$ 99, Agosto de de 2015, pp. 90-91.

** Editor-coordenador da editora da Fundação Ukuma, Lisboa, Portugal. Jornalista, ensaísta e escritor. 
Angola (MPLA) rejeitado o marxismo-leninismo e se inclinado para o que designou como socialismo democrático, próximo das democracias europeias, transformações que culminaram no início dos anos 1990, embora começassem a desenvolver-se antes, com bastantes peripécias.

Entendendo o conceito paradoxo como o que é contrário à opinião geralmente admitida, à previsão ou à verosimilhança, o autor não deixa, por outro lado, de apontar outro paradoxo, o Paradoxo Americano, pois, enquanto o governo de Washington não reconhecia o regime do MPLA e o hostilizava a pretexto da presença militar cubana em território angolano, a petrolífera americana Cabinda Gulf Oil Company (CABGOC) era responsável pela mais volumosa receita de Angola e tinha as suas instalações, em Cabinda, salvaguardadas de sabotagens pelas tropas cubanas. Um cartoon publicado em 8 de Fevereiro de 1986 pelo Washington Post caracterizará bem esta situação paradoxal: «Ronald Reagan quer dar apoio ao guerrilheiro (Savimbi) treinado pelos chineses, financiado pelos sul-africanos para atacar instalações petrolíferas americanas, guardadas por tropas cubanas a pedido do governo marxista angolano. E a Casa Branca pede o apoio do povo americano».

Salientando que no contexto da Guerra Fria foi fundamental o apoio dos países socialistas a Angola, permitindo ao governo de Luanda defender a sua soberania, dado o apoio americano à Frente Nacional de Libertação de Angola (FNLA) desde 1962, e que os conflitos africanos actuais e recentes decorrem do carácter inacabado, ainda em vias de desenvolvimento, dos estados africanos, Nunes Pereira lembra, por outro lado, citando uma advertência de Isabel Castro Henriques, que a «Angola dos nossos dias é o resultado de uma história complexa, onde se combinam as escolhas africanas e as pressões europeias».

Efectivamente, como lhe afirmará em 1994 o então presidente da 824 Assembleia Nacional de Angola, Roberto de Almeida, «nos primeiros quinze anos de independência, a preocupação maior era com a defesa da soberania, com a consolidação da independência e que nos últimos quatro anos, era procurar esclarecer aos seus parceiros ocidentais que Angola, desde as mudanças constitucionais do início dos anos 1990, não era mais governado por "um regime comunista”». De certo modo, reiterava o que o presidente José Eduardo dos Santos tinha declarado em 1992 ao Expresso de Lisboa: «Aqui, o socialismo foi uma intenção, talvez não tenha passado do papel. $O$ 
Estado nacionalizou uma série de empresas em 1976/1978 porque elas estavam abandonadas. Não tinha alternativa».

Como diz Nunes Pereira, «embora a polaridade central do paradoxo seja a contradição entre uma economia crescentemente dependente do Ocidente em contraste com a adopção de um modelo de Partido-Estado marxista, um dos aspectos menos centrais, mas igualmente importantes, foi a construção (forçada pelas circunstâncias e movida por uma aguda luta política, não só intra-partidária, mas com outros sectores da sociedade angolana) de uma economia espartilhada por uma estatização, absurdamente abrangente e ultra-centralizada, que é obrigada a conviver com um forte "enclave" capitalista que domina os dois principais polos da produção angolana».

A tentativa de abertura ao Ocidente foi uma realidade ainda no tempo do presidente Agostinho Neto, cujo governo teve consciência, desde cedo, do agravamento do paradoxo e de que para o desmontar, isto é, resolvê-lo, teria que se aproximar, com urgência, para a esfera económica do Ocidente. Se houve atrasos ou até às vezes alguns recuos tal ficou a dever-se à política «globalista», vincada pela hostilidade, típica da Guerra Fria, dos Estados Unidos da América, sobretudo a partir da invasão soviética no Afeganistão, e ao belicismo renovado dos sul-africanos, o que obrigou a reforçar a dependência angolana político-militar do Leste.

O representante norte-americano na Organização das Nações Unidas (onu), Andrew Young reconhecia que «Nós devemos também compreender que a presença russa e cubana em Angola, embora lamentável e contraproducente para a paz, não constitui necessariamente uma ameaça aos interesses norte-americanos, nem a presença significa a existência de um satélite comunista no continente», mas ninguém lhe ligava nenhuma.

A componente ideológica era mais forte do que a situação no terreno. Mas tal era apenas por simples casmurrice. Na verdade, para quem estava a par do modo de procedimento da União Soviética, era fácil deduzir que a política de Moscovo era sempre triangular. Ela levava em conta, em cada passo, África incluída, os seus interesses, os do país em questão e os das suas relações globais com os Estados Unidos, assegura o autor. Efectivamente, assinala Nunes Pereira, «a manutenção da coexistência pacífica sempre esteve acima dos interesses soviéticos em África. Foi sempre evidente, até à crise angolana de 1975, que nenhuma das duas 
superpotências possuía interesses substantivos na África, muito menos na subsahariana».

E citando, John Marcum, considerado o maior historiador norteamericano do nacionalismo angolano, lembra: «Se a reacção norteamericana à crise angolana, em nível global, foi inepta, a sua total desconsideração pelas realidades da política a fricana foi ainda mais crucial. [...] Acima de tudo, a política norte-americana não soube compreender a política negativa da África do Sul na política africana. Quanto mais os Estados Unidos se tornaram dependentes da cooperação tácita com a África do Sul para combater a penetração soviética, mais abriram caminho à intervenção dos soviéticos, pois afastaram a possibilidade de uma oposição unida a essa intervenção [...] Não há dúvida de que os Estados Unidos foram coniventes com a intervenção sul-africana e tentaram apoiá-la».

Como assinala Manuel Inácio dos Santos Torres no prefácio, «parece-nos, pois, de todo gratificante e animador, que na sequência do primeiro reconhecimento internacional da nossa independência nacional por esse país irmão, o Brasil, tenha sido um cidadão brasileiro a dar luz aos factos e um contributo inestimável à aquisição desses conhecimentos».

\section{Rodrigues Vaz}

Jornalista, escritor e ensaísta, começou por exercer longa actividade jornalística em Angola. Em Luanda, colaborou nos diários A Província de Angola e Diário de Luanda e nas revistas Noite e Dia, Semana Ilustrada e EF. No Diário de Luanda, onde entrou em 1972, foi sub--chefe de redação em 1973, ao mesmo tempo que fazia neste vespertino a coordenação do seu suplemento "Artes e Letras», e se iniciava na crítica de cinema e frequentava o curso superior de Economia, onde co-fundou o Círculo Universitário de Cinema de Luanda. Depois de ter trabalhado durante vários anos como assistente de programação da Angola Filmes, publicou o livro O Alvorecer do Cinema (edição do Círculo Universitário de Cinema de Luanda, 1969). Após a revolução de 25 de Abril de 1974, integrou a equipa que reabriu o matutino $O$ Comércio de Luanda, onde esteve até Setembro de 1974. Convidado, entrou para os quadros da Emissora Oficial de Angola, estrutura de que viria a resultar a Rádio Nacional de Angola (RNA). Posteriormente, integra o quadro fundador da Televisão Popular de Angola (TPA), com o escritor José Luandino Vieira, de que foi adjunto até Maio de 1977, ocasião em que regressa à Rádio Nacional de Angola com o cargo de Chefe do Serviço Internacional. Regressado a Portugal, no 
início da década de 1980, exerceu de 1982 a 2000, o cargo de chefe da secretaria da redacção do Correio da Manhã, onde, ao mesmo tempo, manteve uma vasta colaboração no âmbito cultural, sobretudo na divulgação de Artes Plásticas, tendo mantido ininterruptamente durante 14 anos a secção Artes Plásticas na revista Tempo Livre do Instituto Nacional de Telecomunicações (INATEL). Actualmente é editor-coordenador da editora da Fundação Ukuma, criada e dirigida pelo Arquitecto Troufa Real, e continua a dar colaboração no âmbito da cultura, nomeadamente nas revistas Cultura e África 21, ambas de Angola, e é Editor da revista Cadernos Culturais de Telheiras, de Lisboa. Publicou, entre outras obras, Angola. Estórias esquecidas (2003); Troufa Real para todas as estações (2014).

[e-mail: mrodriguesvaz@] 